Swarthmore College

Works

History Faculty Works

History

7-1-2012

\title{
Genealogy Of An Execution: The Sodomite, The Bishop, And The Anomaly Of 1726
}

Farid Azfar

Swarthmore College, fazfar1@swarthmore.edu

Follow this and additional works at: https://works.swarthmore.edu/fac-history

Part of the History Commons

Let us know how access to these works benefits you

\section{Recommended Citation}

Farid Azfar. (2012). "Genealogy Of An Execution: The Sodomite, The Bishop, And The Anomaly Of 1726". Journal Of British Studies. Volume 51, Issue 3. 568-593. DOI: 10.1086/665525

https://works.swarthmore.edu/fac-history/47

This work is brought to you for free by Swarthmore College Libraries' Works. It has been accepted for inclusion in History Faculty Works by an authorized administrator of Works. For more information, please contact myworks@swarthmore.edu. 


\section{The Journal of British Studies}

http://journals.cambridge.org/JBR

Additional services for The Journal of British Studies:

Email alerts: $\underline{\text { Click here }}$

Subscriptions: Click here

Commercial reprints: Click here

Terms of use : Click here

\section{Genealogy of an Execution: The Sodomite, the Bishop, and the Anomaly of 1726}

Farid Azfar

The Journal of British Studies / Volume 51 / Issue 03 / July 2012, pp 568 - 593

DOI: 10.1086/665525, Published online: 21 December 2012

Link to this article: http://journals.cambridge.org/abstract S0021937100003348

How to cite this article:

Farid Azfar (2012). Genealogy of an Execution: The Sodomite, the Bishop, and the Anomaly of 1726. The Journal of British Studies, 51, pp 568-593 doi:10.1086/665525

Request Permissions : $\underline{\text { Click here }}$ 


\title{
Genealogy of an Execution: The Sodomite, the Bishop, and the Anomaly of 1726
}

\author{
Farid Azfar
}

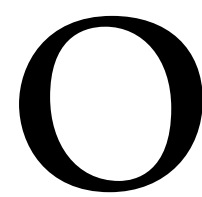

n 9 May 1726, a milkman by the name of Gabriel Laurence (sometimes spelled "Lawrence") was hanged at Tyburn after being prosecuted for committing the crime of sodomy. ${ }^{1}$ Laurence was one of forty men arrested when the authorities raided Mother Clapp's molly house in the Holborn district of London; of these forty, three were executed, including Laurence, who was the first to be sentenced. ${ }^{2}$ Many came forward to attest to his character, among them his father-in-law and the man who supplied him with milk. "Several others deposd," the Old Bailey noted, "that he was a very sober Man, and that they had often been in his Company when he was drunk; but never found him inclinable to such Practices. Guilty. Death." ${ }^{3} \mathrm{He}$ was hanged alongside two other men present that night at Mother Clapp's molly house: William Griffin and Thomas Wright.

Farid Azfar is assistant professor of history at Swarthmore College. He was previously a Mellon postdoctoral fellow and visiting assistant professor of history at Haverford College, where this article was workshopped in the Hurford Center for the Arts and the Humanities 2010-11 Mellon Faculty seminar "Sex, State, and Society in the Early Modern World." He is grateful to the members of this seminar-Lisa Jane Graham, Israel Burshatin, Bethel Saler, Cristina Beltran, Gus Stadler, and Jerry Miller-for helping make this a better piece. Thanks also to Tim Hitchcock and Gary Ferguson for the encouragement they provided at different stages; reviewers and editors at the Journal of British Studies, for their extremely helpful comments and suggestions; Charlotte Bax, for some superb work as a research assistant; numerous librarians, in London, Oxford, and St. Andrews, for helping navigate this paper trail; and Tim Harris and Deborah Cohen, for their continual support.

${ }^{1}$ The event itself is vividly described in chap. 3 of Rictor Norton's excellent Mother Clap's Molly House: The Gay Subculture in England, 1700-1830 (London, 1992).

${ }^{2}$ Mother Clapp's one was one of at least seventeen houses active at this time. Fifty-six men were charged. See Randolph Trumbach, "Modern Sodomy: The Origins of Homosexuality, 1700-1800," A Gay History of Britain: Love and Sex Between Men since the Middle Ages, ed. Matt Cook (Oxford, 2007), 84.

${ }^{3}$ Court proceedings from the trial of Gabriel Laurence, April 1726, Old Bailey Proceedings Online (http://www.oldbaileyonline.org), t17260420-64.

Journal of British Studies 51 (July 2012): 568-593

(C) 2012 by The North American Conference on British Studies.

All rights reserved. 0021-9371/2012/5103-0004\$10.00 
To a reader of eighteenth-century legal records, the executions of 1726 seem at the first instance to be puzzling. Accusations of sodomy were not, in this period, likely to lead to execution. As Tim Hitchcock has observed, "the most important conclusion to draw from the history of the persecution of homosexuality in London is that it was spasmodic and relatively uncommon at any time. Most of the members of the molly-house culture could feel relatively safe throughout the period, assured that to be prosecuted for felonious sodomy and executed, one would have to be horribly unlucky." "To execute three men for sodomy in the same instance was, in this sense, excessive by the standards of the time.

It is perhaps for this reason that the executions of 1726 have so thoroughly exercised the historical imagination. They are key to a narrative in which a homophobic fear of effeminacy leads to state-sponsored "pogroms" against sodomites. The narrative begins with Randolph Trumbach's seminal 1977 article on the molly house, according to which, "sodomitical effeminacy . . . threatened the boundaries of culture as much as sodomy itself." Many sodomites were effeminate and all sodomites were portrayed as such. ${ }^{6}$ In much of his subsequent work, Trumbach makes a series of connections - some more explicit than others-between these portrayals and patterns of punishment. The sodomites, he writes, were seen as a third gender: not necessarily feminine but always associated with the scourge of effeminacy. "All were members of a third gender that deserved to be treated with contempt. They were hanged in the few cases where anal penetration and seminal emission could be proven." In passages like this, it is assumed to be self-evident that cultural intolerance would manifest itself in capital punishment. ${ }^{8}$ Watered down versions of Trumbach's argument-repeatedly contested, yet widely influential-reappear throughout the historiography of eighteenth-century homosexuality. Ned Ward, notes Laurence Senelick, described the molly house in "the bemused tone of an urban tourist; the mood of the 1720s was more juridical and prejudicial. The number of trials for sodomy increased, bespeaking a greater public awareness of the subculture." Here again, the spike in prosecutions is linked to a rise in cultural intolerance: together they constitute this "juridical and prejudicial" mood. The operative assumption, that law and culture march in lockstep, also underlies George Haggerty's argument that Gabriel Laurence died not just for his sexual proclivities but because ideas of sexual possibility were constrained by the dictates of class: love between men was conceivable for aristocrats but not for

\footnotetext{
${ }^{4}$ Tim Hitchcock, English Sexualities, 1700-1800 (New York, 1997), 72.

${ }^{5}$ Randolph Trumbach, "London's Sodomites: Homosexual Behavior and Western Culture in the 18th Century," Journal of Social History 11, no. 1 (Autumn 1977): 13.

${ }^{6}$ Ibid., 27.

${ }^{7}$ Randolph Trumbach, "Sex, Gender, and Sexual Identity in Modern Culture: Male Sodomy and Female Prostitution in Enlightenment London," Journal of the History of Sexuality 2, no. 2 (October 1991): 190.

${ }^{8}$ The same series of sentences reappears, for instance, in Randolph Trumbach, Sex and the Gender Revolution, vol. 1, Heterosexuality and the Third Gender in Enlightenment London (Chicago, 1998), 8. There is one key change: "they were hanged" is replaced with "some were hanged."

9 Laurence Senelick, "Mollies or Men of Mode? Sodomy and the Eighteenth-Century London Stage," Journal of the History of Sexuality 1, no. 1 (July 1990): 50.
} 
milkmen, and Laurence, according to Haggerty, was executed for crossing that invisible barrier. ${ }^{10}$

Parallel to the narrative in which heightened homophobia causally connects to a rise in executions is one in which "pogroms" against homosexuals, starting in the 1690s and peaking in the 1720s, testify to a well-oiled machinery of state. In his seminal and formative work on this topic, Alan Bray uses the word "pogroms" to describe the raids and trials that peaked in 1726. "The Pogroms" is the title of Netta Goldsmith's brief section on the raids of 1726, drawn, as she acknowledges, from the existing historiography, including Bray. ${ }^{12}$ The "containment of a population," writes Anthony Simpson, "is but a step away from pogrom and, according to Bray, in this delicate balance the Societies for the Reformation of Manners tipped the scale toward repression." 13 The word "pogrom" was first applied to the Warsaw pogrom of 1881 and has since been used to describe popular, spontaneous, moblike attacks on Jews and their communities, including those that occurred in premodern Europe. In the molly house historiography, the word becomes tied to a vision of state power that informs these historians' conception of the Societies as agents of a unified state, executing its dictates with seamless precision. " "There is little doubt," writes Bray, "that behind the trials of 1726 we can see the all-too-effective activity of the Societies for the Reformation of Manners." 15 "Had the Reform Societies wished to persecute molly-houses in a systematic way," writes Simpson, "they could have done so."16 The word also signals a sense of comprehensiveness; not only was this "state" efficient, it was also unrelenting. For Cynthia Herrup, the arrest in 1698 of a group of "buggers" led by a Captain Rigby "proved to be the first in a series of early-eighteenthcentury prosecutions so extensive that one of today's leading historians of male homosexuality discusses them as "pogroms." 17 Here we get a sense of the kind of work that the word "pogrom" does, how it contains and diffuses a vision of a state that was extraordinarily extensive and unfailingly efficient in its eradication of these sexual undergrounds.

The two narratives I have outlined here-of cultural intolerance and state power, respectively, leading to a spike in persecution-have dominated the scholarship. These narratives have also shown a great propensity for synthetic reinforcement. We see this, for instance, in David Kuchta's allusion to the mollies in his larger argument about the rise of a "modest masculinity" in late Stuart England: "Unlike in Tudor-Stuart England, in 'the modern relationship between sexual behavior and gender' which emerged in the eighteenth century, homosexual practices were

\footnotetext{
${ }^{10}$ George Haggerty, Men in Love: Masculinity and Sexuality in the Eighteenth Century (New York, 1999), 58-59.

11 "The raids and trials of 1726 were not the first time that pogroms of this kind had taken place"; Alan Bray, Homosexuality in Renaissance England (London, 1982), 91.

${ }^{12}$ Netta Goldsmith, The Worst of Crimes: Homosexuality and the Law in Eighteenth-Century London (Aldershot, 1998), 8.

${ }^{13}$ Anthony E. Simpson, "Masculinity and Control: The Prosecution of Sex Offences in EighteenthCentury London” (PhD diss., New York University, 1984), 704.

${ }^{14}$ I am grateful to Robert Beachy for the clarification.

${ }^{15}$ Bray, Homosexuality in Renaissance England, 90.

${ }^{16}$ Simpson, "Masculinity and Control," 707.

${ }^{17}$ Bray's argument here is also cited by Cynthia Herrup in A House in Gross Disorder: Sex, Law, and the 2nd Earl of Castlehaven (Oxford, 2001), 134.
} 
incompatible with masculinist political culture, which led to increased state repression of 'mollies' in the late seventeenth and early eighteenth centuries . . . prosecutions of homosexual practices (and executions of men committing them) doubled after 1688, since homosexual practices were seen as inherently associated with effeminacy. . . It is this new - and essentially modern-political homophobia, as much as the growth of a permanent homosexual subculture, that explains the 'pogroms of the eighteenth century." 18 The word "pogroms" seems to support throwaway allusions to "state repression," especially as it works in concert with the word "doubled" and the phrase "political homophobia." 19 The history of the law is used, as such, to embellish the narrative of a decisive ideological shift; that narrative, in turn, seems to compellingly explain these legal developments. Thus extracted, legal evidence acquires a powerful teleological logic. It becomes almost unnecessary to demonstrate the correlation, for everything begins and ends with the fear of effeminacy: prosecutions suggest an intolerance for effeminacy; intolerance explains an apparent enthusiasm for prosecution. Not much room is left for an alternative explanation of why prosecutions would double after 1688 .

Kuchta should not be singled out - the molly house raids are not his primary concern, and this passage is itself a pastiche of quotes from the secondary literature, including Bray and Trumbach. But it is precisely for this reason that his deployment of these arguments is interesting. ${ }^{20}$ He suggests, in his synthesis of the existent historiography, that the overall impression it has created of a medium-term cultural process and a medium-term political process converging in the early eighteenth century and coming to a crescendo with a wave of executions in 1726. And while many, in their way, have challenged this picture of cultural, political, and legal coherence, ${ }^{21}$ the culture-state-law connection continues to dominate the historiography. ${ }^{22}$

To some extent, the endless repetition of this narrative comes from the recycling

${ }^{18}$ David Kuchta, The Three-Piece Suit and Modern Masculinity: England, 1550-1850(Berkeley, 2002), 100-101.

19 Ibid.

${ }^{20}$ In his discussion of the mollies, Kuchta cites Trumbach, Haggerty, Bray, Senelick, Richard Davenport-Jones, and an unpublished paper by Thomas Alan King. In his footnotes (Three-Piece Suit, nn. 214-15), he challenges aspects of this historiography, arguing that King's is "the best discussion of the mollies' relation to political culture" $(215)$ and concluding that "the modern connotations of homosexual practices cannot be understood outside the very process of repression" (215). However, his analytical inhibitions about the argument provided by Trumbach, Bray, and others are mostly removed from the narrative he draws in the main text.

${ }^{21}$ For challenges to the effeminacy thesis, see Michelle Cohen and Tim Hitchcock, introduction to Hitchcock, English Masculinities, 5; Michele Cohen, review of Sex and the Gender Revolution: Volume One: Heterosexuality and the Third Gender in Enlightenment London, by Randolph Trumbach, Social History 26, no. 1 (January 2001): 90; Steve Poole, “Bringing Great Shame Upon the City': Sodomy, the Courts, and the Civil Idiom in Eighteenth-Century Bristol," Urban History 34, no. 1 (May 2007): 118 .

${ }^{22}$ Hence Katherine Crawford returns to 1726 in her survey of European sexualities and cites the case of Gabriel Laurence to support the larger point that the visibility of molly houses was enough to inspire persecution; European Sexualities: 1400-1800 (Cambridge, 2007), 204. Peter Hennen, in an examination of the specific effeminacies of the molly house, makes it a point to draw a connection between the "starkly moralistic terms" in which "the general public interpreted the whole affair" and the "swift and terrible" nature of the persecutions; Faeries, Bears, and Leathermen: Men in Community Queering the Masculine (Chicago, 2008), 54. 
of sources. From Trumbach's early work to more recent interventions by Tanya Cassidy and Peter Hennen, the historiography of the molly house has been dominated by two bodies of texts: the records of the Old Bailey and narrative accounts such as Ned Ward's History of London Clubs (1709). ${ }^{23}$ "The story of the 1726 homosexual witch-hunt," writes Dan Cruickshank, "can be told best and most directly through the texts of the Old Bailey proceedings." 24 It behooves us to interrogate this assumption. While it is certainly true that the Old Bailey records are compelling, riveting, and rich enough to reward repeated returns, the story they tell is profoundly partial, a fragment of a fragment of the whole. Especially when used to serve dual purposes-barometers of cultural change and evidence of a politico-legal shift-they leave intact the synchronous narrative of legal, political, sexual, and social development. ${ }^{25}$ What is lost, here, is a sense of the contingency and randomness of these records-the fact that the law is what Dror Ze'evi has called a "treacherous mirror"; or, as Leslie Pierce has written, that "the written record of a case . . cannot . . . be viewed as a mirror of human events and emotions but rather as a prism that transforms separate streams of experience into a narrative focused to satisfy a particular set of requirements." ${ }^{26}$

The article that follows returns to 1726 and offers a different point of entry to the case of Gabriel Laurence, presenting evidence which confounds the argument that the latter's execution is final proof of a neat alignment of state power and a cultural intolerance of the effeminate other. It examines a body of archival material that has yet to be explored by historians of sexuality: clerical correspondence. These records, like the Old Bailey or Ned Ward's account, are partial. But they do offer a serious challenge to the existing scholarly narrative. They reveal, for instance, a concerted aristocratic campaign to save Gabriel Laurence, who had been convicted on the basis of tarnished evidence, which came from a man, Mark Partridge, who was himself a well-known sodomite. In this campaign, members of the aristocracy - two dukes and an earl—took Laurence's case to the king and obtained a reprieve, as a result of which the case then became a subject of delib-

\footnotetext{
${ }^{23}$ Edward Ward, The Secret History of London Clubs: Particularly the Kit Cat, Beef-Stake, Virtuosos, Quacks, Knights of the Golden-Fleece, Florists, Beans, etc. (London, 1709). For a recent article that relies on Ward and the Old Bailey, see Tanya Cassidy, "People, Place, and Performance: Theoretically Revisiting Mother Clapp's Molly House," in Queer People: Negotiations and Expressions of Homosexuality ed. Chris Mounsey and Caroline Gonda (Lewisburg, PA, 2007), 99-113. An exception to this rule is Goldsmith, The Worst of Crimes, which uses records from the King's Bench, from the 1730s onward. It contains a very brief section on 1726 that sums up the historiography and is tellingly entitled "the pogroms." However, Goldsmith finds some interesting cases of legal intervention in the post-1730 period-cases like that of Laurence that do not set a pattern and deserved detailed inquiry of their own.

${ }^{24}$ Dan Cruickshank, London's Sinful Secret: The Bawdy History and Very Public Passions of London (London, 2010), 62.

${ }^{25}$ Hence Cruickshank writes that "the Old Bailey records suggest that attitudes to homosexuality changed during the first quarter of the eighteenth century," and, tracing the now-familiar pattern, remarks that "in 1726 there was a dramatic reversal" (London's Sinful Secret, 62). While he occasionally distinguishes between the culture of the courts and that of the city, he mostly reads one as indication of the other; hence one defendant's defiant response was "a brave answer with which most sentient people in London during the 1720s must surely have agreed, in private at least" (71); see also 75-76.

${ }^{26}$ Dror Ze'evi, Producing Desire: Changing Sexual Discourse in the Ottoman Middle East, 1500-1900 (Berkeley, 2006), 48; Leslie Pierce, Morality Tales: Law and Gender in the Ottoman Court of Aintab (Berkeley, 1993), 102.
} 
erations at the highest levels of power. This, in turn, inspired a counterreaction from another quarter of the state: the ecclesiastical authorities. It was in the wake of extensive efforts spearheaded by Edmund Gibson, bishop of London, and involving other important men in his network-Secretary of State Charles Townshend, Attorney General Philip Yorke, and Archbishop of Canterbury William Wake-that Laurence was ultimately executed. And there is, as this body of documents establishes, much to suggest that Gibson might not have accomplished his mission-that he only succeeded due to the complex contingencies of the time. Laurence, in other words, was caught in a moment of social and political crossfire: a crisis of moral authority that emerged as the cultural chaos of 1720s London tested the already vexed relationship among ecclesiastical, legal, and political actors. Laurence's execution testifies as much to the bishop of London's heightened sense of vulnerability as it does to a rising fear of effeminacy. His execution did not just occur despite incoherence, sporadic resolve, undefined purpose, and limited effectiveness; it occurred, I argue, because of all these things. It might well have been a remarkable event in the persecution of homosexuality, but it was not a remarkable event in the moral-political crisis of the 1720s.

In venturing in this direction, I travel along a path that was originally marked by Anthony Simpson in his detailed and insightful dissertation. "While it may be right to attribute the emergence of this subculture to the characteristics of urban life, it does not," Simpson notes, "seem reasonable to go on from this to explain the periodic pogroms in terms of the mobilization of the resentment which greater visibility of homosexuality evoked. We should rather seek to determine what these pogroms represented, who organized them, and how far the prosecutions resulting from them represented statements of popular opinion." ${ }^{27}$ My reservations about the word "pogroms" aside, I take Simpson's charge very seriously. Central to my argument is an insistence on the anomaly of 1726. As historians of homosexuality have observed, repeatedly, the executions of 1726 did not set a long-lasting pattern. ${ }^{28}$ Raids and prosecutions certainly continued. In July, for instance, two of the men present at Mother Clapp's molly house were sentenced to the pillory alongside Mother Clapp herself. ${ }^{29}$ But they were not, as it happens, executed. In fact, of the thirteen men tried at the Old Bailey between September 1727 and December 1750, either for "sodomy" or "assault with sodomitical intent," three were sentenced to be executed: in 1728,1730 , and $1738 .^{30}$ There were as many individuals executed for sodomy at the Old Bailey in 1726 as there were in the next quarter-century as a whole. After 1730, as Netta Goldsmith has written, "there was a sharp reduction in the number of sodomy cases which reached the Old Bailey. Over the next couple of decades or so never more than one or two

${ }^{27}$ Simpson, "Masculinity and Control," 704-5.

${ }^{28}$ Goldsmith, The Worst of Crimes, 8 .

29 Old Bailey Proceedings Online (http://www.oldbaileyonline.org), July 1726, trial of William Brown (t17260711-77); July 1726, trial of Martin Mackintosh (t17260711-53); July 1726, trial of Margaret Clap (t17260711-54).

${ }^{30}$ Between September 1727 and December 1750, thirteen men were tried for sodomy before the Old Bailey, of whom six were found guilty and three were executed. See Old Bailey Proceedings Online (http://www.oldbaileyonline.org), October 1728, trial of John Bleak Cowland (t17281016-16); August 1730, trial of Gilbert Laurence (t17300828-24); February 1738, trial of Samuel Taylor John Berry (t17380222-5). 
cases of this kind were heard in the central criminal court in any twelve-month period, while five years could go by without any being heard at all." ${ }^{31}$ Where the punishment of sodomy is concerned, the mid-1720s were outstandingly draconian, and, within this period, May 1726 stands out as the harshest month of all. It was an anomalous month in an anomalous year-suggesting that it was the anomaly of 1726, not the anomaly of effeminacy, which best explains the executions. The fact that the inhabitants of molly houses were herded into prisons, and some of them executed, is consistent with the notion of a spasmodically intensifying intolerance for effeminacy, but one does not clearly or fully explain the other. An exceptional convergence of legal, political, social, and moral pressures lies behind the execution of Gabriel Laurence. The state was involved inasmuch as it was in the benefit of particular actors to ensure that Laurence was executed at this time; the need to execute him had much to do with the particularities of the balance of power, within the state, in the mid-1720s. Failed attacks on drolls and masquerades, the floundering fortunes of the Societies for the Reformation of Manners, the affective lives of men in power and the social bonds that tied them to each other: together these contingencies sealed Laurence's fate. It is cultural incoherence and cultural confusion, and not an illusory consensus between state, law, and culture, that best explain what happened in 1726 .

This article, to an extent, is an interpretive experiment. I am interested in what happens to our perceptions of power and its relationship to sexuality when we stop using historical evidence-from sermons to legal records-to weave linear metanarratives that extend across decades and focus instead on the complex contingencies of a particular moment. If, as Maurice Godelier has written, "it is not just sexuality which haunts society, but society which haunts the body's sexuality," then we cannot understand this haunting if we draw one clear line. Instead, we must engage diverse trajectories of influence, the multiple lines of causality that exist, at any given time, between society and sexuality. ${ }^{32}$ To focus on this multiplicity is, I suggest, politically useful, for it helps clarify how power works. "This literature," writes Tim Hitchcock of the field of eighteenth-century homosexuality, "has created its own martyrs and villains, and has played a significant role in the contemporary politics of gay liberation." ${ }^{33}$ If this is in fact true, then we need a better depiction of the battleground on which these martyrs and villains fought; moreover, by focusing on the contingencies of prosecution we open up realms of political possibility that might otherwise seem inaccessible. Because of our compulsive focus on the linear, and on finding explanatory parallels, we have perhaps overlooked what Foucault describes as "the moving substrate of force relations which, by virtue of their inequality, constantly engender states of power." ${ }^{34}$ By focusing, as I do, on the papers of a bishop, and what they reveal about the execution of a sodomite, I hope to reveal how power is produced incrementally and, to an extent, haphazardly, "produced from one moment to the next, at every point, or rather in every relation from one point to another." 35

${ }^{31}$ Goldsmith, The Worst of Crimes, 58.

${ }^{32}$ Maurice Godelier, "The Origins of Male Domination," New Left Review 127 (1981): 17.

${ }^{33}$ Hitchcock, English Sexualities, 60.

${ }^{34}$ Michel Foucault, The History of Sexuality, vol. 1, An Introduction (New York, 1990), 93.

${ }^{35}$ Ibid. 
Let us start, then, with the city. What kind of place was London in the 1720s, the diocese of Bishop Edmund Gibson? To a great extent, it was an extreme version of what it had been since the Reformation: prosperous, expanding, diseased, stratified, and crime-ridden. ${ }^{36}$ The last, especially, seemed to present a particularly intractable problem. As John Beattie has written of the early eighteenth century, "much of the evidence that the law was failing to deter crime and the determination to find alternative weapons arose from the metropolis . . . an urban world that was finding the problems of crime and social order increasingly difficult to contain." ${ }^{37}$ In the years preceding the executions, authorities in London were deluged by a bewildering array of challenges, from the Waltham Blacks to the Atterbury Plotters, from celebrity criminals to a sausage-maker who was "publickly whipped through the Streets of the City, for selling Sausages made of Horse Flesh." ${ }^{38}$ In 1725 , a gang of Russian criminals terrorized areas of the city and sent waves of panic rippling across the various strata of administration. "No time should be lost in suppressing a Knot of desperate Rogues," Secretary of State Charles Delafaye wrote to Hardwicke, "they are not to be dealt with in the ordinary way." 39 This last phrase is indicative of the legislative mindset: Delafaye was calling for a paradigm shift, one that resulted in what E. P. Thompson has described as "the floodtide of eighteenth-century retributive justice." ${ }^{40}$ Just three years before the sodomy executions of 1726, the Black Act had created fifty new capital offenses, the most famous of which made it a capital crime to dress up in black and poach the king's deer. ${ }^{41}$ The act was preceded by a series of strenuous crackdowns on all kinds of urban crime. ${ }^{42}$ A royal proclamation in 1719 offered an outstandingly generous reward for the conviction of a London robber: it topped off the $£ 40$ that parliament had already granted with a whopping extra $£ 100$. With the Transportation Acts of 1718 and 1720, the central government directly financed and legally licensed the transportation of convicted felons. ${ }^{43}$ A rising enthusiasm for persecution is unmistakably revealed in the legal records. Between 1700 and 1710, fifteen individuals were convicted of pickpocketing and six were executed; between 1720 and 1730, 221 individuals were accused and thirty-six executed. ${ }^{44}$ And the drive

\footnotetext{
${ }^{36}$ This is too vast a literature to survey here, but the starting point is Dorothy George, London Life in the Eighteenth Century (London, 1966). E. P. Thompson, Whigs and Hunters: The Origin of the Black Act (New York, 1975) probably remains the most compelling account of the early 1720s.

${ }^{37}$ John Beattie, "London Crime and the Making of the 'Bloody Code,' 1689-1718," in Stilling the Grumbling Hive, ed. Lee Davison, T. Hitchcock, T. Keirn, and R. Shoemaker (Stroud, 1992), 70.

${ }^{38}$ St. James's Journal, 22 December 1722.

${ }^{39}$ Charles Delafaye to Philip Yorke, 7 February 1725/6, British Library (BL), Add. MSS 36136, fol. 7; see also Richard Jones to Charles Delafaye, 7 February 1725, BL, Add. MSS 36136, fol. 11.

${ }^{40}$ Thompson, Whigs and Hunters, 244-45.

${ }^{41}$ Ibid.

${ }^{42}$ J. M. Beattie, "Crime and Inequality in Eighteenth-Century London," in Crime and Inequality, ed. John Hagan and Ruth D. Peterson (Stanford, CA, 1995), 116-39.

${ }^{43}$ J. M. Beattie, "Sir John Fielding and Public Justice: The Bow Street Magistrates' Court, 17541780," Law and History Review 25, no. 1 (Spring 2007): 6.

${ }^{44}$ Old Bailey Proceedings Online (http://www.oldbaileyonline.org), results from a search for all offenses (January 1700-December 1710) where offense category is pocketpicking and punishment category is executed; results from a search for all offenses (January 1720-December 1730) where offense category is pocketpicking and punishment category is executed.
} 
for punishment is there as well in the rhetoric. Some felt the Transportation Act to be excessively lenient: "Terror will cost you less than Love," went one of its critics, "and be better attended, for People will do that for Fear, which they will refuse upon any other Obligation." 45

To understand the sodomy prosecutions, then, we must discard the image of a polite 1720s, with a dark center of fear occupied by the sodomitical other. But we should not replace it with the image of a state that went after miscreants with a frenzied zeal, for that too does not get us very far. The existence of a repressive penal atmosphere provides, at best, a limited explanation of the sodomy prosecutions. The fervor for prosecution did not, to begin with, affect all crimes equally; prostitution, for instance, was punished with decreasing severity. In the years preceding the executions, the Societies for the Reformation of Manners had been undermined on several fronts: first, by the men and women of London, who were increasingly hostile to its oppressive moral policing; and second, by the judicial system, which persistently challenged its focus on summary judgment with new ideas about proof and due process. In 1725, the Societies' use of general warrants in the arrest of suspected prostitutes was deemed "irregular and illegal" by the Westminster bench of justices. This was a pivotal event in what Faramerz Dabhoiwala has described as "the gradual disintegration of their judicial approach," which, he has suggested, was "key to their ultimate downfall." 46 From a penal perspective, then, 1720s London was a far better place to be a prostitute than a pickpocket and as the decade proceeded, it became better and better for prostitutes. It was in this context that Bernard Mandeville wrote Modest Defense of Public Stews, lampooning the Societies and arguing that the solution to a variety of social problems lay in the institution of government-sponsored brothels. ${ }^{47}$ In a prefatory address to the Societies' governors, he evoked the vibrant popular opposition to their efforts: "Your Endeavours to support Lewdness," he gleefully observed, "have only serv'd to promote it." 48 That the text went on to enjoy "tremendously wide circulation" and became "the starting point for all further eighteenth-century discussion of the topic" tells us something about the place of the Societies in the popular imagination around the year $1725 .^{49}$ It suggests, moreover, how the crisis of social disorder was, for someone like Gibson, exacerbated by a crisis of moral disorder.

The sodomy executions of 1726 occurred, then, in the midst of two countervailing developments: a decreased institutional tolerance for certain crimes and an increased tolerance for others. We must temper our reading of Modest Defense- and its spectacular reception-by keeping in mind the fate of pickpockets who were, at this time, being sent to the scaffold in droves. Together, these contradictions

${ }^{45}$ [Anon.] Political Reflections for the Year, 1722, \&c With Observations on the Conduct of Some Great Ministers of State (London, 1723), 14.

${ }^{46}$ Faramerz Dabhoiwala, "Sex and Societies for Moral Reform, 1688-1800," Journal of British Studies 46, no. 2 (April 2007): 309.

${ }^{47}$ Philo-Porney [Bernard Mandeville], Modest Defense of Publick Stews: Or, An Essay on Whoring (London, 1725).

${ }^{48}$ Modest Defense, iii.

${ }^{49}$ See Faramerz Dabhoiwala, "Lust and Liberty," Past and Present 207, no. 1 (2010): 145. On the Modest Defense controversy, see William Speck, "Bernard Mandeville and the Middlesex Grand Jury," Eighteenth-Century Studies 11, no. 3 (Spring 1978): 362-74. 
illuminate the space of openness and irresolution in which penal measures were enacted. "The fact was," writes Anthony Simpson in an excellent article on Francis Chartis's 1730 trial for raping a servant, "that confusion rather than toughness came to characterize the law of rape in England in this period." ${ }^{50}$ The confusion surrounding rape was symptomatic, it seems, of a broader social confusion. And as confusion allowed for creative license in matters of punishment, it could equally prevent or facilitate execution.

A document from the papers of Bishop Gibson suggests how this license impacted the penal treatment of sodomy. Right around the time when the Societies were being stripped of their persecutory power, an anonymous figure, possibly a member of the Societies, made a list of prosecutions for assault with sodomitical intent at the Colchester Quarter Sessions. This list, which now lies in Gibson's papers, was sent to him at an undetermined date, although judging from the details of the prosecutions it cites, it seems that it was written in 1725 or perhaps in early $1726 .{ }^{51}$ In 1704 and 1719 , it notes, a man was convicted of assault with sodomitical intent and fined $£ 10$. He paid the fee and was discharged. The same thing happened in 1719 and 1724 , but the men, in both cases, were let off with $£ 7$. When this happened again, a few months later, the court increased the fine. As the document explains: "the Court perceiving that the small fines heretofore Imposed on those Occasions were not sufficient to deferr from Crime. . . . Of these Crimes, They therefore thought fitt to sett a Larger fine." ${ }^{52}$ And so this man was charged $£ 50$ and ordered to find sureties of his good behavior for the twelve months that followed. The very next day, another man was convicted. The court, as the document noted, observed that this "Odious Practice" had become more common than before and, fearing that this was due to the pecuniary nature of the fines, resolved to commence with corporal punishments. ${ }^{53}$ The man was ordered to sit in the pillory for an hour. The same thing happened, very soon after, to a "Charles Littleproud." The final entry concerned a man with the name of Matt Cashbert, who was said to be a "most Abominable Offender . . . who had long made it his Business to Seduce Young Men into this most Detestable Practice." He was ordered to be set in the pillory twice in one day, and then publicly whipped about the market. He was accordingly pilloried but, as the document proceeds to note, was so "Dismally Complimented by the Populace in their Usuall way" that magistrates were subsequently advised to remove the whipping part of the sentence. $^{54}$ The document then ends.

There is no one reading of this document, and it is important, when analyzing it, to practice what Melissa Mowry has called "a hermeneutic of archival suspicion" or an "epistemology of the archive that recognizes the social and political contin-

\footnotetext{
${ }^{50}$ Anthony Simpson, "Popular Perceptions of Rape as a Capital Crime in Eighteenth-Century England: The Press and the Trial of Francis Charteris in the Old Bailey," Law and History Review 22, no. 1 (Spring 2004): 182.

${ }^{51}$ List of People Convicted of Sodomy at Colchester Quarter Sessions, 1704-1724, Bodleian Library, MS Eng. C. 3190, fols. 65-66.

${ }^{52}$ Ibid.

${ }^{53}$ Ibid.

${ }^{54}$ Ibid.
} 
gencies of the documents themselves." 55 We do not know if Gibson, bishop of London, commissioned this document, nor do we know how it influenced him if he did. Still, we can draw some tentative conclusions. It suggests (but does not prove) that the rise of corporal punishment for sodomy resulted not from an increased intolerance for effeminacy but from the apparently persistent failure of pecuniary and noncorporal punishments. Effeminacy does not concern its author, who distinguishes between serious and minor offenders mostly by virtue of their recidivism. More generally, it challenges the impression, prevalent in the historiography, of purpose, coherence, and resolve. It confirms that execution was not preordained. Nor was it dictated by a clear, consistent, and definable theory. Execution does not figure in this matrix of possible punishments; it lurks, instead, as an absent, unmentioned possibility - a conclusion toward which it seems to veer before it ends abruptly. It is confusion that comes through most vividly. The document suggests how this confusion could combine with a sense of desperation, arising from the apparent intractability of the problem, and how this confused desperation could enable creative license when it came to the treatment of sodomy. This license could just as easily decrease severity as it could increase it, if the removal of the sentence in the last instance is any indication. It suggests that we should exercise patience before we extrapolate clear cultural or juridical shifts from patterns of punishment. Often, it seems, they are less reflective of a clear and defined policy than they are of an episodic inventiveness enabled by a growing ambiguity. Often they are not products of coherent theories so much as reactions to the absence of theories.

It was in this atmosphere of confusion, conflict, and innovation that Mark Partridge, an embittered sodomite, brought Mother Clapp's molly house to the attention of the Societies' informers. Partridge's motivations are murky at best, but it seems that revenge and self-protection were both high on the list. "The discovering of the Molly Houses," as the trial of Thomas Wright (hanged along with Laurence) indicates, "was chiefly owing to a Quarrel betwixt Mark Partridge and Harrington: For upon this Quarrel Partridge to be revenged on Herrington [sic], had blab'd something of the Secret, and afterwards gave a large Information of a great many others. " ${ }^{56}$ Harrington does not appear in the Old Bailey, but Laurence does. That Laurence was Partridge's prime target is also suggested by the State Papers. In one deposition, from 8 April 1726, he claims to have seen Laurence compromise himself sexually "at diver houses noted for entertaining Sodomites," including Mother Clapp's. ${ }^{57}$ In another deposition, from 14 April, he professes to have sodomized Laurence himself: at the end of the act, they had (he alleges) joked about Laurence having a baby boy, which they would raise to be a councilor so "that he may appear for the Sodomites \& Jacobites." ${ }^{58}$ It is an

\footnotetext{
${ }^{55}$ Melissa Mowry, "Sex and the Archives: Current Work on Subordinate Identities and Early Modern Cultural Formation," Journal of British Studies 44, no. I (January 2005): 179.

${ }^{56}$ Old Bailey Proceedings Online (http://www.oldbaileyonline.org), April 1726, trial of Thomas Wright (t17260420-67).

${ }^{57}$ The Voluntary Information of Mark Partridge taken before me and his Majesties Justices of the Peace for the said County, 8 April 1726, The National Archives (TNA): SP 35/61, fol. 213.

${ }^{58}$ The Voluntary Information of Mark Partridge taken upon Oath before US his Majesties Justices of the Peace of the said County whose names are underwritten, 14 April 1726, TNA: SP 35/61, fol. 221 .
} 
utterly bizarre document, in which Partridge implicates himself thoroughly, truly stretching the guarantee given to an informer, in the course of painting the most terrible picture conceivable of Laurence. It seems very likely that Laurence was being framed so Partridge himself could go free, which, as it happens, he did.

Whatever Partridge's motivation, these documents seriously challenge the impression that the executions of 1726 were the natural result of the Societies' steady and unrelenting persecutory energies. Indeed, it took a lot of convincing for the informers to agree on Partridge's undercover mission. A document from the papers of William Wake, archbishop of Canterbury (seemingly written in the same hand as the list of convictions for sodomitical assault) confirms that the informers could "hardly give credit to what this man so confidently reported" and that it was with "much difficulty" that four men agreed to this mission. ${ }^{59}$ This was not uncharacteristic of the Societies, whose informers were seasoned practitioners of "don't ask, don't tell" when it came to the molly houses. As one contemporary complained, "it is frequent for our Justices to be inform'd of Assemblies of these detestable People, with no other Notice, than exclaiming against the Vice of the Age, without using the Authority they are entrusted with to make it less Vicious, as their Offices, and even the Principles of Nature require." ${ }^{60}$ In the absence of Partridge's intervention, the same might have happened in the case of Laurence. It was only after he goaded informers into Mother Clapp's molly house that a report was issued to the Attorney General and the government commenced the prosecutions. The story of Laurence's execution did not then begin with the downward-looking eyes of the state but the upward-looking eyes of a subject eager to use the state in his own struggle for retribution or, perhaps, self-preservation.

It did not, however, take very long for the state to get involved. Mark Partridge might not have known it but he was setting in motion a minor political earthquake. Laurence, as we know, had been convicted on the basis of tarnished evidence, obtained from confessed sodomites (including a certain Thomas Newton who also testified against him). At the same time, more than one person had come forward to defend Laurence by attesting to his good character, his father-in-law among them. Partridge, meanwhile, had no such defenders. In this case, it might have seemed that the roles were being reversed: the accused, who had an air of sobriety and abject passivity, was being victimized by a person who had all the outward characteristics of a perpetrator. For Rictor Norton, this explains why the executions were a one-off event: "The court may have sensed a witch-hunt atmosphere in the proceedings, not so much because the victims were innocent, but because the accusations came almost solely from only two men, both of whom were particeps criminens in every instance, and both of whom were demonstrable rogues of dubious credibility." ${ }^{\prime \prime}$ The peaking of prosecutions in 1726 does suggest a kind of panicked retraction by the authorities - an epiphanic horror at what they had done. What Norton does not consider is that this legal problem almost saved

\footnotetext{
59 "An Account of the Prosecution of the Actors of that Profane Droll called the Prodigal Son which Your Grace recommended to be prosecuted . . . A Short Account of the Sodomites in London, Westminster, and Southwark," n.d., Christ Church College Library, Wake MS 231, Wake Letters 27, fol. 185 .

${ }^{60}$ [Anon.] Law Quibbles. Or, a Treatise of the Evasions, Tricks, Turns and Quibbles, Commonly Used in the Profession of the Law, to the Prejudice of Clients, and Others (London, 1724), 13-14.

${ }^{61}$ Norton, Mother Clap's Molly House, 60.
} 
Laurence from the scaffold. A letter from Edmund Gibson to William Wake, archbishop of Canterbury, dated 8 May, tells of how three aristocrats-the earl of Essex and the dukes of Rutland and Richmond-had learned of the case and sought to overturn the ruling. They had obtained a reprieve from the king and then accosted Charles Townshend, Walpole's powerful secretary of state and Gibson's chief political ally, at the opera. ${ }^{62}$ Townshend then informed Gibson of what they had said, which Gibson, in turn, relayed to the archbishop:

\begin{abstract}
They told him, they had represented to the King the hardship of Gabriel Lawrence's case (the first of the Sodomites now convicted) for being condemn'd upon a single Evidence who was particeps Crimins, and as his character is very good, and supported by numbers of creditable persons. They added, that upon this representation made to the King, they had obtain'd a Reprieve, and desir'd Lord Townshend to assist them in saving the man. My Lord told them he could not do it; and he afterwards said to the King what he thought proper against it, but without effect. He is gone to Clermont today, to dine with the Duke of Newcastle; but before he went, he gave order for sending Mr. Paxton to me, that I might acquaint him with what the Lords had said, and hear what he had to say concerning Lawrence's character. ${ }^{63}$
\end{abstract}

The rest of the letter reveals Gibson as consolidating his power and marshaling it against the heady confluence of forces that were making his mission, and that of the Societies, increasingly difficult to enforce. He tells Wake that he dispatched Assistant Solicitor Nicholas Paxton to further investigate Laurence's case; Paxton, in turn, had returned with evidence of how Laurence was facing a second indictment in Middlesex. Moreover, he had managed to obtain two reports from "persons of entire reputation." ${ }^{64}$ Gibson promises to secure these depositions and assures him that Paxton would carry them to Townshend at nine o'clock that evening. "In the mean time," he tells Wake, "the Reprieve is kept unsigned." 65 He then ends the letter with a bid for Wake's support in this matter: "I thought it my duty to acquaint your Grace with what has pass'd, as I also told my Lord Townshend that I would, and the case of Lawrence being such as I have represented above, I am still willing to hope that your joint Endeavours may defeat the Attempts that are made to rescue this vile Creature from the hand of Justice." ${ }^{\prime \prime 6}$

Gibson eventually had his way. A documentary trail confirms the implementation of these orders. On 8 May, another deposition was drawn, in which two of the Societies' constables, Joseph Sellers and Samuel Stevens, further attested to having witnessed Gabriel Laurence engaging in sodomitical acts. ${ }^{67}$ No stone was left unturned in the mission to execute Laurence. There is even a document from the gaol deliverer at Newgate, confirming that Laurence was in custody. ${ }^{68}$ On 9 May, he was executed.

\footnotetext{
${ }^{62}$ Edmund Gibson to William Wake, 8 May 1726, Christ Church College Library, Wake MS 231, Wake Letters 27, fol. 186.

${ }^{63}$ Ibid.

${ }^{64}$ Ibid.

65 Ibid.

${ }^{66}$ Ibid.

${ }^{67}$ The Information of Joseph Sellers and Samuel Stevens, 8 May 1726, TNA: SP 35/62, fols. 14-15.

${ }^{68}$ Certificate of the Clerk of the Peace of a Bill being found in Middlesex against Gabriel Lawrence for Sodomy, 7 May 1726, TNA: SP 35/62, fol. 12.
} 
Like the chart from Gibson's papers, the letter from Gibson to Archbishop Wake supports multiple readings. We might read it, first, as a slow-motion account of the machinery of state being set in motion against a deviant individual. Such a reading would not be entirely inaccurate; it is buttressed, after all, by the supporting documents, which confirm what Gibson tells the Archbishop. But such a reading would also be profoundly partial. It would avoid what the letter suggests about a state divided around matters of punishment and, specifically, punishment for sexual offenses. The fact that the accused should garner aristocratic support (and the fact that the conviction should require such a determined effort from powerful men) suggests deep fault lines at the heart of the state. At the very least, it complicates the narrative of "pogroms" and "state-sponsored repression," and reminds us of Foucault's important point about the "strictly relational character of power relationships"-how "their existence depends on a multiplicity of points of resistance" which "play the role of adversary, target, support, or handle in power relations." ${ }^{69}$ Members of the aristocracy had successfully used the law to influence the monarch against the persecution of a sodomite. It is, for these purposes, irrelevant that they had not succeeded in sustaining their influence. There was a moment when Laurence could have been saved, and a number of conditions had to be satisfied for this moment to lead to the moment of his execution. If the three aristocrats had not cornered Townshend at the opera, Townshend would not have called for Gibson. The aristocrats' ability to obtain a reprieve from the king and Gibson's and Townshend's ability to counter that move with moves of their own both point back to the creative legal confusion represented in the chart of punishments and, beyond, the tense penal atmosphere of the period, as represented, for instance, in the declining fortunes of pickpockets and rising fortunes of prostitutes. Moreover, the letter itself alludes to other relevant factors: the fresh evidence, Paxton's support, and the timing of the whole affair. In all these ways, it further underscores the contingency of the execution.

The most critical contingency of all, perhaps, was Gibson's-and Townshend's-zeal: the fact that they made it their personal mission to ensure the execution of Gabriel Laurence. It was only because of their own extrajudicial efforts, and decidedly not because of any kind of regular mechanism, that they were able to bring this about. "The Societies," writes Dennis Rubini, "aided patriarchy through their antisodomitical raids and entrapments, which came to have a life of their own." ${ }^{\prime 70}$ To say that they had a life of their own is to remove the Societies from the orbit of history. These documents confirm that the Societies' actions at the height of their activities to suppress the molly houses were far from selfsustaining. They relied very clearly on the manipulative urges of particular historical actors - in this case, Mark Partridge, Edmund Gibson and Charles Townshend.

To explain the prosecution, then, we might continue by asking why these powerful men were thus propelled. Let us start with Gibson. Townshend was also critical-and I will consider his role in pages that follow-but the letter clearly insinuates that Townshend expected Gibson to handle the case, and there is no

\footnotetext{
${ }^{69}$ Foucault, History of Sexuality, 95.

${ }^{70}$ Denis Rubini, "Sexuality in Augustan England: Sodomy, Politics, Elite Circles and Society," in The Pursuit of Sodomy: Male Homosexuality in Renaissance and Enlightenment Europe, ed. Kent Gerard and Gert Hekma (New York, 1998), 358.
} 
reason to suppose that Gibson would have pursued it with such tenacity had he not been completely invested in it himself. It is true that, as Norman Sykes has noted, he was a figurehead for the Societies, but the question still remains: why did he throw so much energy behind this particular case ${ }^{71}$ What comes through above all is that Laurence's conviction doubled as a kind of public statement intended for all his real and imagined enemies, including the aristocrats who had jumped to Laurence's defense. By attempting this rescue, they were reminding Gibson of how justice itself was falling out of the hands of the clergy and into the hands of lawmakers. It is because the aristocrats had succeeded, or were about to succeed, that Gibson experienced the rush of motivation that this letter exudes. It was not just about sodomy anymore, it was about defeating the forces that wanted to rescue this "vile creature from justice."

To explain this rush, we might consider the nature of his competition. The three aristocrats who took Laurence's case to the king were, far from marginal, wellregarded and well-connected. Before and after the executions, the state had rewarded them with a series of promotions and honors. ${ }^{72}$ William Capell, earl of Essex, was eulogized as "one of the Lords of his Majesty's Bedchamber, Captain of the Yeomen of the Guard, one of his Majesty's most Hon. Privy Council, and one of the Knights Companions of the most Noble Order of the Garter." ${ }^{73}$ Lennox served as a go-between for the Hanoverian aristocracy, in one case writing a letter to Sarah Churchill, the duchess of Malborough, when a member of the royal household wanted to switch boxes with her at the opera. ${ }^{74}$ In another exchange of letters, John Manners, duke of Rutland, successfully played a number of prominent statesmen off each other in order to secure the appointment of his friend, a Mr. Vernen, to a post at the Collegiate Church of Manchester. ${ }^{75}$ Charles Townshend was among his various pawns. It was months after this event that he would join Richmond and Essex in accosting Townshend at the opera. And it was with this knowledge of his and the others' tenacity and standing that Townshend went to Gibson and Gibson went to Wake.

Why did the aristocrats take up the case of Gabriel Laurence? The cliché of the effeminate, sodomitical aristocrat does not really help us here. For whatever it is worth, these men all displayed the outward markers of masculinity. Richmond, in fact, is best known as the founder of modern cricket; Rutland was a veteran at races and cockfights. ${ }^{76}$ Nor should we suppose that they were gay crusaders. As Anthony Simpson has insightfully observed, it is "dangerous to take capital prosecutions as an indication of the strength of feeling against homosexuals. Those

\footnotetext{
${ }^{71}$ Norman Sykes, Edmund Gibson: Bishop of London, 1669-1748; a Study in Politics \& Religion in the Eighteenth Century (London, 1926), 191, 193, 195-97.

${ }^{72}$ Evening Post, 21-24 May 1726. See also Daily Journal, 9 March 1726; Weekly Journal or British Gazetteer, 28 May 1726; and London Gazette, 24-28 May 1726.

${ }^{73}$ Daily Gazetteer 2356 (January 10, 1743).

${ }^{74}$ Charles Lennox, duke of Richmond to Sarah Churchill, duchess of Marlborough, 9 November 1727, BL, Add. MSS 61476, fol. 207.

${ }^{75}$ John Manners to Henry Pelham, 21 June 1725, BL, Add. MSS 32687, fol. 89; Sarah Churchill; John Manners to Henry Pelham, 11 August 1725, BL, Add. MSS 32687, fol. 139.

${ }^{76}$ Lennox is mentioned throughout the historiography of cricket. See John Marshall, The Duke Who Was Cricket (London, 1961). See also Universal Spectator and Weekly Journal, 6 September 1729; and London Evening Post, 4 July 1728. On Rutland's interest in gaming and cockfights, see Mist's Weekly Journal, 13 August 1726; and Weekly Journal or British Gazetteer 1 April, 1727.
} 
who hated them may have had their own reasons for discouraging their prosecution." 77 For all these reasons, it is important not to reduce this case to a twoparty struggle between a puritanical clergy and flamboyant aristocracy. It is critical to remember that the law was also involved. Indeed, there is no reason to believe that the aristocrats' defense of Laurence was not for the reason they stated: the fact that Laurence was all but certainly framed by a man who was particeps criminis.

In order to more fully understand the nature of this challenge, it is important that we pay close attention to timing. As Dabhoiwala writes, "it was precisely during the years when the societies came in for the most criticism that they racked up the greatest number of prosecutions." ${ }^{78}$ We must keep this point in mind when correcting a misconception that pervades the scholarship. "After the hangings in August 1726," notes Netta Goldsmith, "this particular moral crusade lost momentum, mainly because the authorities and the general public reacted against the Societies. The special constables they recruited to stamp out vice were found to be both officious and corrupt." ${ }^{79}$ But declining tolerance for the Societies and their methods preceded the executions, and only if we recognize this can we truly gauge the force of feeling which led to the executions. In reacting to the Societies' questionable standards, the three aristocrats were riding the crest of a wave of opposition. The legal argument that they were employing-one that critiqued the Societies' failure to observe due process-was the same as that which had successfully been used, months earlier, to wrench from the Societies their moral, legal, and political power vis-à-vis prostitutes. It is additionally relevant that Modest Defense of Publick Stews had appeared in the previous year and was making waves at this time. Whether or not they were inspired by Mandeville, the three aristocrats were mirroring a cultural trend in attacking the Societies. The nature of their argument added to the political significance of their attempt. This helps explain Gibson's and Townshend's need for a symbolic victory. The Societies, as William Speck has shown in his account of the prosecution of Mandeville's Fable, had an established practice of making examples (often working through proxies such as the Middlesex Grand Jury) of those they believed were threatening their mission. ${ }^{80}$ As Speck writes in conclusion: "By presenting The Fable of the Bees the Middlesex Grand Jury was not merely getting its own back on Mandeville for his snide remarks on charity schools; they were censuring what has been called 'the most telling critique of the humanist values dear to the Opposition." "s1 Gibson, like the Middlesex Grand Jury, was in cahoots with the Societies. Also like the Jury, he seemed to be using an individual case to make a larger statement. By ensuring the execution of Gabriel Laurence he would be sending an important message to the three aristocrats and to everyone else who had attacked the Societies, from the courts to the aristocrats to Bernard Mandeville, that they could not do so with impunity. When he sat down to write his letter to Wake, he did so with the knowledge that highly influential men were out to damage an institution he very much cherished,

\footnotetext{
77 Simpson, "Masculinity and Control," 454.

${ }^{78}$ Dabhoiwala, "Sex and Societies for Moral Reform," 309.

${ }^{79}$ Goldsmith, The Worst of Crimes, 8-9.

${ }^{80}$ William Speck, "Bernard Mandeville," 373.

${ }^{81}$ Ibid., 374, citing Isaac Kramnick, Bolingbroke and His Circle: The Politics of Nostalgia in the Age of Walpole (Cambridge, 1968), 203.
} 
using the same weapon - a particular legal argument- that had recently been used to deliver a series of debilitating blows to the same institution. His obsession with ensuring Laurence's execution is best interpreted as an act of political countertheater: a reaction to the Societies' decline, not just a premonition of it.

Gibson's obsession may also be embedded in the history of his tense and fluctuating relationships with two powerful men: Charles Townshend, secretary of state and Philip Yorke, attorney general. Townshend's decision to apprise Gibson of attempts being made to secure the release of Laurence was an event in the history of homosexuality-Laurence's execution was contingent upon it-but it was also an event in the formation of his relationship with Gibson. The years leading up to 1726 were a honeymoon period for Gibson and Townshend, but a honeymoon that was always on the verge of turning bitter. "I have just cast my Eye on your proposal about the Charity Schools," Townshend had recently written, in a characteristically obsequious letter to Gibson, "and I like your thoughts very much, as I always find that your proposals find extremely to the good of the Church, and the Service of his Majesty's Government." 82 Such vociferous declarations of loyalty would not have been necessary if the alliance between these men was solidly secured. It was, in fact, markedly fragile. In a letter to Townshend, Gibson said he was sorry to acquaint him with "the great Complaints and general dissatisfaction "which were upon the Bench, and "to see all matters relating to the Church and Clergy treated in Parliament with such coldness and indignity." "The load," he insisted, "falls very heavy upon me, and I think I deserve a little compassion." ${ }^{83}$ It is clear from these lines that the two men were close; it is also clear that high expectations of reciprocity tested their relationship continually.

There are few things, perhaps, that tested it more than the masquerades. The commercial masquerade had come to London in 1718, attracting Londoners rich and poor to attend in the hundreds and, on certain nights, the thousands. ${ }^{84}$ In 1724, not long before Laurence's execution, Gibson spearheaded an effort to shut them down. ${ }^{85}$ In a series of letters, he asked Townshend to represent the bishops' case to the king. ${ }^{86}$ These letters are fascinating for their affective complexity: administrative inactions are turned, repeatedly, into personal offenses. It was "with the greatest grief," he wrote in one, that he heard the masquerades were going to be opened again; he "did not believe it, considering the great goodness of his Majesty, in expressly prohibiting them at the humble request of his faithful Bishops, upon a former attempt to revive them." ${ }^{87} \mathrm{He}$ reminded Townshend how he, as bishop, was "immediately affected by it" and entreated him "in the most earnest

\footnotetext{
${ }^{82}$ Charles Townshend to Edmund Gibson, 19 September 1724, University of St. Andrews Library, Gibson MS 5193.

${ }^{83}$ Draft letter from Edmund Gibson to Charles Townshend, n.d., University of St. Andrews Library, Gibson MS 5208.

${ }^{84}$ Terry Castle, Masquerade and Civilization: The Carnivalesque in Eighteenth-Century English Culture and Fiction (Stanford, CA, 1986).

${ }^{85}$ See Sykes, Edmund Gibson, 187-91, for a full description of his efforts.

${ }^{86}$ On the control of masquerades, see University of St. Andrews Library, Gibson MS 5213-5218, fol. 37-40. See also Draft Letter from Wake and Other Bishops, n.d. (Control of Masquerades), Christ Church College Library, Wake MS 231, Wake Letters 10, fol. 111.

${ }^{87}$ Edmund Gibson to Charles Townshend, n.d., University of St. Andrews Library, Gibson MS 5215, vol. 4, fol. 37 .
} 
manner," to use his "interest with the King" to renew the said prohibition. ${ }^{88} \mathrm{He}$ ominously concluded by reminding Townshend that His Majesty's Government's "chief Reliance must be upon the sober and serious part of the Nation," which, he was sure, would "be greatly troubled" if they found that the masquerades had "Countenance from the Court." 89

Many things were happening here. First, Gibson was making it clear that he would take it personally if the masquerades were resumed. Second, he was reminding Townshend of his deficit in social credit-the fact that he operated in a network of political reciprocity, where backing and cooperation were forms of currency. It is relevant, then, that Townshend did not come through effectively, and Gibson ultimately failed in his efforts to shut down the masquerades. The parliamentary session of 1726 opened with a masquerade reputedly "so infamous that even some of the great patrons of that diversion were scandalized at it." ${ }^{90}$ It was months after this that Townshend came to Gibson with the case of Laurence. One might wonder, then, if Townshend was thereby attempting to forestall an impending explosion of conflict. In either case, the fact that Gibson had lost the masquerade battle after all his behind-the-scenes maneuvering illuminates the urgency of his need to win another one. A victory against the molly house might not have been a victory against the masquerade, but it was partial compensation for Gibson's defeat by pro-masquerading forces, especially when it doubled as a volley against the three peers who had come to the defense of Gabriel Laurence.

One more case, involving a failed attempt at suppressing a droll, further elaborates on Gibson's need for a symbolic victory, and the complexity of the field of play in which this victory was secured. Ever since their inception in the early 1690s, as A. G. Craig has shown, the Societies had tried to shut down, or, at the very least, restrict the duration of Bartholomew Fair. They had not been successful. As Craig writes,"prohibitions on the fair's activities tended to have no more than a seasonal effect at most"; restrictions attempted in 1702 were "dismal failures." Defiant performers, eager crowds, a profoundly unsupportive and undermining court: all hampered the Societies' efforts. ${ }^{92}$ In 1724, Gibson was presented with the case of a blasphemous droll titled "The Prodigal Son," which had for several years been performed at Bartholomew Fair. ${ }^{93}$ Particularly pernicious were scenes of irreligion, whoring, and disobedience, as well as the egregious behavior of an

\footnotetext{
${ }^{88}$ Ibid.

${ }^{89}$ Ibid.

${ }^{90}$ Portland MSS, vii, 420, 260, cited in Norman Sykes, Edmund Gibson.

${ }^{91}$ See A. G. Craig, "The Movement for Reformation of Manners, 1688-1715” (PhD diss., University of Edinburgh, 1980), 156, 158.

${ }^{92}$ For some of the popular sentiment against the restriction of Bartholomew Fair to three days, see The Pigs' Petition Against Bartholomew Fair (London, 1708).

${ }^{93}$ For more on this, see James E. May and Calhoun Winton, "The 'Prodigal Son' at Bartholomew Fair: A New Document," Theatre Survey 21 (May 1980): 63-72. In an engaging and thought-provoking analysis, May and Winton broach the question of why this play was prosecuted in the King's Bench, and not the Court of Common Council, where a case such as this would ordinarily have been prosecuted. They suggest that this had something to do with a symbolic need to reassert the powers of censorship at a time when these powers had been severely threatened.
} 
actor named John Harper. ${ }^{94}$ Here as in the case of Laurence, Gibson made it his personal mission to defeat what he saw as the abuse of power in support of the forces of depravity. As he wrote to the Attorney General Philip Yorke:

I am doing all that is in my power to obtain a Revocation of the favour granted to that vile man, Harper; by speaking to my Lord Townshend last night, and by writing to Sir Robert Walpole in the most earnest manner this evening. In the mean time, I desire that no further step may be taken in it, till they have reconsider'd this matter, and have determin'd either for or against me; for I think my self bound in duty, to oppose it in the strongest manner I can; and if I do not prevail, liberavi animan [I have freed my soul]. ${ }^{95}$

This letter has many of the same ingredients as Gibson's letters to Townshend and Wake on the subject of the molly house executions: a consciousness of his own isolation bordering on a martyr complex, deference spiked with intense antagonism, a call to arms cloaked as a bid for support. The backdrop to this document is Gibson's fraught and complex relationship with the Attorney General Philip Yorke, earl of Hardwicke-a relationship best described as one of conflictual interdependence. The two men often worked side by side: fellowships, commissions, royal mandates for universities-all required their combined efforts. ${ }^{96}$ But the two men also had differing priorities. Hardwicke, for instance, was notoriously uncommitted to prosecuting the enemies of religion. ${ }^{97}$ It is not completely surprising, then, that Gibson would have adopted this peculiar tone with him. Nor is it particularly surprising that he did not prevail in the case of Harper. His letter to Hardwicke did not, it seems, have its required effect. ${ }^{98}$

What this means for the case of Laurence is strongly suggested by a paper from the archives of Archbishop Wake, a two-page document telling two short narratives: "An Account of the Prosecution of the Actors of that Profane Droll called the Prodigal Son which Your Grace recommended to be prosecuted" and "A Short Account of the Sodomites in London, Westminster, and Southwark." ${ }^{99}$ It is written

${ }^{94}$ Richard Williams to Edmund Gibson, 16 December 1724, Christ Church College Library, Wake MS 231, Wake Letters 27, fol. 183; see also Wake MS 231, Wake Letters 27, fols. 176-81 and 184.

${ }^{95}$ Edmund Gibson to Philip York, earl of Hardwicke, 11 February 1725, BL, Add. MSS 35585, fol. 34.

${ }^{96}$ Gibson's correspondence with Hardwicke reflects a range of different concerns-college fellowships, ecclesiastical commissions concerning the plantations, royal mandates at academic institutions - that required their combined attention. Edmund Gibson to Philip Yorke, 7 October 1725, BL, Add. MSS 35585, fol. 24; Edmund Gibson to Philip Yorke, 8 November 1725, BL, Add. MSS 35585, fol. 29; Edmund Gibson to Philip Yorke, 11 February 1726, BL, Add. MSS 35585, fol. 34; Edmund Gibson to Philip Yorke, 18 April 1726, BL, Add. MSS 35585, fol. 36; Edmund Gibson to Philip Yorke, 22 September 1726, BL, Add. MSS 36136, fol. 109; Edmund Gibson to Philip Yorke, 22 September 1726, BL, Add. MSS 36136, fol. 111; Edmund Gibson to Philip Yorke, 18 September 1726, BL, Add. MSS 36136, fol. 113.

${ }^{97}$ Philip C. York, The Life and Correspondence of Philip Yorke Earl of Hardwicke Lord High Chancellor of Great Britain (New York, 1977), 82.

${ }^{98}$ For more on the details of this, see May and Winton, "The 'Prodigal Son' at Bartholomew Fair."

99 "An Account of the Prosecution of the Actors of that Profane Droll called the Prodigal Son which Your Grace recommended to be prosecuted . . . A Short Account of the Sodomites in London, Westminster, and Southwark," n.d., Christ Church College Library, Wake MS 231, Wake Letters 27, fol. 185 . 
in the same hand as the document listing punishments for assault with sodomitical intent, suggesting that it was penned by a member of the Societies for the Reformation of Manners. The first of the two narratives it tells is one of failure. Once the accused had been prosecuted in the King's Bench "according to the usual course of proceedings in the like case," the clerk in the crown employed by the prosecutors received a notice from the attorney general ordering him to put an end to Harper's prosecution, "and thereupon the Prosecutors were advised by the Council not to proceed any further against the other actors." ${ }^{100}$ The second is a narrative of limited success. It was with "much difficulty" that the Societies' informers were prevailed upon to enter Mother Clapp's molly house; once they did, their findings were "laid before the Attorney Generall and thereupon the Government ordered prosecutions to be carried out against them."101

Like the chart of executions, the document suggests an attempt at finding meaning through narrativization. The divergence of these dual narratives was apparently being used to incite a kind of heuristic revelation across the higher echelon of the administration. The attorney general's office could not, it seems, be relied upon to do the Societies' bidding, as the case of the drolls suggested. Nor could it be antagonized completely, as the case of the sodomites suggested. The message, if there was one, was a message of diligence: moral reform was under attack, and a single move could make the pivotal difference. The document thus invites its reader to contemplate the contingencies of prosecution and, by so doing, impresses on him the severity of the situation and the urgency of immediate action.

The document also raises questions that are impossible to answer with certainty. What does it mean that the attorney general's office undermined Harper's prosecution before it facilitated that of Laurence? Was the attorney general using Laurence to save his faltering relationship with the bishop? We cannot know for sure. We can, however, establish without a shadow of a doubt that the two cases were mentally linked. This is rendered manifest by the fact that they are described in the same document. It is more than likely that Gibson's defeat in the first case would have contributed to the zeal that went into the second. The victory against Laurence was embedded, it is clear, in a history of defeat.

The document also confirms that the case of Laurence emerged at a time when a variety of actors - the Societies, the clergy, the courts, and the state-were in the midst of a heated struggle for moral and institutional authority. For this reason, these relationships were inherently undefined, constantly forming, perpetually under pressure, and always on the verge of complete disintegration. The randomness of urban life, with its relentless outpouring of unforeseeable problems, made these relationships all the more treacherous to navigate. It is in this environment that Gibson operated and because of this environment that he had to make a strategic display of power. Laurence might not have been executed had Gibson not intervened, and Gibson might not have intervened if his place in the matrix of power had been more certain-in both senses of the word. In the conventional narrative of the molly house phenomenon, an actor like Gibson could act with certain knowledge of his success; we see, here, how his actions were fueled by uncertainty in every sense. There was the generic uncertainty that faces every powerful actor

${ }^{100}$ Ibid.

${ }^{101}$ Ibid. 
in every state-an uncertainty over how much power she or he has-and the particular uncertainty of Gibson's place in mid-1720s London: an uncertainty surrounding whether the attorney general was likely to take his side in a case against sodomy when he had been indifferent in a case concerning blasphemy, an uncertainty that reflected the precarious moral status of the church and, at the same time, the uncertain nature of his fraught relationship with men like Townshend and Hardwicke. At every level, this uncertainty was compounded by the residual weight of Gibson's authority, his demonstrated ability to successfully exert his considerable power on several occasions, under particular conditions. We must, for this reason, add the uncertainty of his political authority to the list of contingencies that led to the execution.

The nature of this uncertainty, and the moment's contingencies, are further illumined if we glance briefly, by way of conclusion, toward the immediate future. Also in the summer of 1726, Gibson would be faced with another urban challenge: the sensational success of Henley's Oratory. Starting in July 1726, dissenting preacher John Henley began to use the second floor of a house in Newport Market as a meeting room for public lectures on secular as well as religious subjects, from the machinations of the spleen to the arts of public speaking. Visitors had to pay to enter and did so, in part, for the Orator's flamboyance and theatrical antics. On 8 September 1726, Gibson wrote to Townshend, bringing this "new sort of Conventicle" to his attention, suggesting that it portended the turning of "Religious Assemblies into Theaters \& Stages, to which people repair, not for the ends of Devotion, but only for curiosity and comfort." 102 He made a point of drawing Townshend's attention to the fact that an unregulated outer door led to an inner door, which was guarded by a man who screened visitors, thus contravening the fourth provision of the Toleration Act, which forbade dissenters from locking, barring, or bolting their doors during the time of their meetings. This, he suggested, was grounds enough for prosecution.

In writing to Townshend, Gibson was likely emboldened by the molly house executions of 1726 and, at the same time, alarmed by the meaning of this new development, which made it all too evident that the larger struggle over urban space was far from won. Of this he would be reminded when Townshend solicited Hardwicke's advice, and the latter responded with a letter advising against prosecution. Henley, he confirmed, was stretching the limits of the Toleration Act, but neither its multiple doors nor its ticketing of its entrants, made it a clear contravention of any discernable law. Hardwicke acknowledged the "dangerous consequences" of a space such as this and suggested that a case could, in theory be made, but only as a prelude to advising the government against making it: "I think it my duty not to advice the Administration to engage in a Prosecution without any [prospect of success] the event of which might rather encourage than restrain the mischief it was intended to suppress."103

Hardwicke's behavior in the case of Harper was an augur of things to come. A decade after the molly house raids, he would decide against Gibson in the Middleton v. Crofts case, unbinding the laity from the canons of the Church of En-

${ }^{102}$ Edmund Gibson to Charles Townshend, 8 September 1726, BL, Add. MSS 36136, fol. 63.

${ }^{103}$ Philip Yorke to Charles Townshend, 22 September 1726, BL, Add. MSS 36136, fol. 64. 
gland. ${ }^{104}$ His response is also interesting for the particular philosophy of prosecution it expresses: that the public could not be coerced into submission with a series of penal acts, that it was more than capable at striking back. The city was not an identifiable object of reform but a chaotic field in which acts of control could easily boomerang back on the reformer. Gibson subscribed to this philosophy himself, as he suggested in a letter he wrote to Hardwicke, a year after the Henley debacle, asking for his advice in a case involving a lease: "I would not make the Attempt," he wrote, "unless it be a clear case on my side, and such as the Court cannot well direct the Jury to find against me." He was, he clarified, not thinking himself "obliged to engage in a Suit as Bishop, without a reasonable prospect of Success, especially when it may be attended with Reproach."105 The purposes of this letter are dubious; perhaps he was trying to tell Hardwicke that he expected him to decide in his favor, and perhaps he was just asking for an honest evaluation of his chances. In either case, the letter is interesting for what it reveals about Gibson's fragile sense of public self, the speed and ease with which public opprobrium could shatter his authority. We see this also in an earlier letter to Townshend, about how his antimasquerading crusade would lead to his being "censured by some as Rash by others as seditious, and by others again as enthusiastical." 106 These lines exude a melancholic acceptance of his own vulnerability before the public eye in a hostile urban world that was slipping beyond his control. Gibson would be reminded of this again when he wrote a pastoral letter to the inhabitants of London and Westminster, warning them of the scourge of heterodoxy, only to be one-upped by radical deist Matthew Tindal, who responded with a treatise of his own, attacking the Church on several counts. ${ }^{107}$ Nor was Tindal's an isolated voice. The forces propelling the bishop's abject sense of isolation can be glimpsed in a 1729 letter to Fog's Weekly Journal, penned by a man who claimed to be writing from the country, from where he followed Fog's with steadfast zeal, lamenting the "many Sheets of Infidelity" he had observed, "but nothing in Favour of Religion, except the Bishop of London's Pastoral Letter." 108

It might seem that we are getting quite far from the case of Gabriel Laurence. But the reality is that that the case of Laurence-and, more broadly, the molly house phenomenon-kept redoubling in Gibson's mind as he came to face these mounting challenges to his moral authority. Hence he proudly evoked the raids on Mother Clapp's molly house in his pastoral letter of 1728 as part of his attempt to bring the deviating masses of London and Westminster back into the fold of his moral authority: "A new sort of Vice of a very horrible nature, and almost unknown before in these parts of the World, was springing up and gaining ground among us, if it had not been check'd by the seasonable Care of the Civil Admin-

${ }^{104}$ George R. Bush, "Dr Codex Silenced: Middleton versus Crofts Revised," Legal History 24, no. 1 (April 2003): 23-58.

${ }^{105}$ Edmund Gibson to Philip Yorke, 2 September 1727, BL, Add. MSS 35585, folio 77.

${ }^{106}$ Edmund Gibson to Charles Townshend, 4 December 1724, University of St. Andrews Library, Gibson MS 5216, vol. 4, fol. 28.

${ }^{107}$ Matthew Tindal, An Address to the Inhabitants of the Two Great Cities of London and Westminster: In Relation to a Pastoral Letter, Said to be Written by the Bishop of London (London, 1728), and $A$ Second Address to the Inhabitants of the Two Great Cities of London and Westminster: Occasion'd by A Second Pastoral Letter (London, 1730).

${ }^{108}$ Fog's Weekly Journal, 19 July 1729, no. 43. 
istration." 109 A similar narrative runs through much of the secondary literature on the molly house raids. In one case, a scholar actually cites this passage to drive home a point about the 1720 s difference. ${ }^{110}$ It is important then that we recognize how much the image at the heart of this narrative-an image of smoothness and consistency, of a legal system that worked like clockwork-was clearly at odds with the reality, of which Gibson himself was well aware. This triumphalist narrative of legislative heroism concealed the informers' routine reluctance in cases of this kind and sidestepped the glaringly obvious fact that the executions of 1726 began with an act of blackmail. It studiously avoided the aristocrats' campaign to save Laurence and made no mention at all of the flurry of behind-the-scenes machinations. If his revisionist narrative of the raids testifies to his need to impress the urban public with a rhetorical spectacle of administrative power, there is reason to wonder how much this need affected his drive to secure the execution in the first place. But we need not follow this line of argument in order to acknowledge the larger point, which is that Gibson's dysfunctional relationship with his urban public was, like his many other dysfunctional relationships, a context for understanding the case of Gabriel Laurence.

Apart from issuing volleys of triumphant rhetoric, Gibson attempted to prolong this moment of success by inciting further trials. The next two years saw more raids and more prosecutions, but Gibson was being wildly optimistic when he supposed, in a letter to Delafaye, that they were "in a fair way to suppress that abomination once for all."111 Another wave of raids in the 1760s is but one indication that molly house culture was healthy and vibrant in the decades that followed. ${ }^{112}$ In the 1730s, Gibson would lose Townshend's support along with Hardwicke's when, despite Gibson's attempts to forestall it, Townshend retreated from politics. ${ }^{113}$ Only later would "Walpole's Pope" start to resemble the towering, all-powerful figure that has emerged in the annals of ecclesiastical history. ${ }^{114}$ The raids and executions of 1726 were a product, it seems, of a very specific ecology of power. In May of 1726, Gibson had the nominal support of Townshend and Hardwicke, both of whom were in social debt to him. This was a moment of penal severity and creative license in matters of punishment, a moment when the attack on the Societies made it imperative for Gibson to launch a counterattack, a moment when Gibson, defeated by a city of drolls and masquerades, would have been desperate enough to make a point and capable enough of doing so. These are

${ }^{109}$ Edmund Gibson, The Bishop of London's Pastoral Letter to the People of his Diocese; Particularly, to Those of The Two Great Cities of London and Westminster. Occasion'd by Some Late Writings in Favour of Infidelity (London, 1728), 2.

110 Senelick, "Mollies or Men of Mode?" 50.

${ }^{111}$ Edmund Gibson to Charles Delafaye (for the Duke of Newcastle), 24 May 1726, S.P. Dom. Geo. I, B. 62, cited in Sykes, Edmund Gibson, 196.

${ }^{112}$ For more on this, see Simpson, "Masculinity and Control," 431, 491; Hitchcock, English Sexualities, 67, 73; and Goldsmith, The Worst of Crimes.

113 Sykes, Edmund Gibson, 149.

${ }^{114}$ It is interesting to consider a draft of a letter from Gibson to Walpole, undated but from the mid-1730s. The letter itself is seething with rage at the court's inaction in the face of growing "Antichurch spirits." It contains a note, in Gibson's hand, which seems to have been written retrospectively, saying: "It will easily be seen, by the tenor of this Letter, that when I wrote it, I had no thoughts of an Archbishoprick." See draft letter from Edmund Gibson to Robert Walpole, n.d., University of St. Andrews Library, Gibson MS 5299. 
some of the key intersecting and irreplaceable contingencies behind the execution of Gabriel Laurence.

What, then, is the political or epistemological lesson here? What, for instance, have we learnt about the value of focusing on a particular case or a particular moment? I am inspired, to an extent, by Alan Bray's point that there is "no linear history of homosexuality to be written at all, any more than there is of 'the family' or indeed of sexuality itself." 115 I am wary, however, of Bray's next point: "these things," he writes, "take their meaning from the varying societies which give them form; if they change it is because these societies have changed." 116 If the history of homosexuality is not causally autonomous, if its randomness is the randomness of history at large, then we cannot assume that it moves to the rhythms of whatever we see as a period's most critical transformations. If we are going to embed it in society, then we must embed it more deeply into social chaos, the kind that is produced by the simultaneous functioning of multiple countervailing processes. We must embed it into the realm of the unpredictable.

In the last decade or so, many have made versions of this point. Karen Harvey has critiqued what she calls "a story of an increasingly rigorous and narrow conception of masculinity" that runs through the histories of sexuality written in the wake of Thomas Laqueur's Making Sex. ${ }^{117}$ Harvey writes that "the seamless integration of the Laqueurian vision into some recent works of gender history tends to eclipse the way in which different areas of life-work, domestic arrangements, reproduction, pleasure-are subject to distinct forces for change and persistence." 118 Elsewhere, Sarah Silah, drawing on Eve Sedgwick, observes that "if the emergence of the homosexual (rather like the rise of the bourgeoisie) can be discovered in any period a scholar chooses to examine, it may be that narrative is not the appropriate format for this discussion." 119 Inasmuch as the history of sexuality is now a discipline, Harvey and Silah are part of a discipline-wide paradigm shift. Many others, as H. G. Cocks writes in a literature review, have suggested that "the notions of selfhood" that revolve around modern sexual identity are "localized phenomena dependent on specific practices of class and the structure of life in a particular time and place." ${ }^{120}$

A turn to the specific does not, however, fully define the discipline. In "Lust and Liberty," Faramerz Dabhoiwala argues that scholarly inattention to the most glaring issue in Enlightenment sexuality- "the general rise of permissiveness"-arises from the "ever-growing specialization of social and cultural historians, and their current tendency to value the minute exploration of text, discourse,

115 Bray, Homosexuality in Renaissance England, 104.

116 Ibid.

${ }^{117}$ Karen Harvey, "The Century of Sex? Gender, Bodies, and Sexuality in the Long Eighteenth Century," Historical Journal 45, no. 4 (2002): 908; see also Karen Harvey, Reading Sex: Bodies and Gender in English Erotic Culture (Cambridge, 2005), 10-11.

${ }^{118}$ Harvey, "The Century of Sex," 916.

${ }^{119}$ Sarah Salih, "Sexual Identities: A Medieval Perspective," in Sodomy in Early Modern Europe, ed. Thomas Betteridge (Manchester, 2002), 114.

${ }^{120}$ Harry Cocks, "Modernity and the Self in the Modern History of Sexuality," Historical Journal 49, no. 4 (2006): 1226. 
and subjective experience as the primary ways of understanding the past." ${ }^{121}$ His own article attempts to "revive a more ambitious approach to the history of sex"-to eschew the emphasis, in the canon of intellectual history, on authorial intention and clear transmission in favor of a view of ideas that allows for a "more surreptitious, diffuse, and yet pervasive shift." ${ }^{122}$ The long-term linear shift is, it seems, back with a vengeance.

In insisting on the importance of a moment, then, I am not paving a new path so much as participating in a struggle that lies at the heart of the history of sexuality: a struggle between countervailing impulses for narrativization and particularization, for stretching time and freezing time. But the struggle, I suggest, is ultimately productive, for both kinds of account are needed. The philosophy of history that underlies Dabhoiwala's "Lust and Liberty"-one that privileges messy over neat, inadvertent over intentional-calls for more, rather than fewer, microhistorical analyses. While his own argument moves swiftly forward toward a series of endpoints-Mandeville, Hume, Mill, Bentham - it points, along the way, at the overwhelming complexity of each of these particular moments. For instance, to prove the point that the discourse of sexual permissiveness was increasingly being used to defend sodomy, he cites a statement made by Thomas Newton, accused of having sodomized Gabriel Laurence: "I did it because I thought I knew him, and think there is no Crime in making what use I please of my own Body." ${ }^{123}$ Newton's statement occupies multiple temporalities: that of a shift that occurred over a century, and that of a moment that occurred in 1726. As it travels across the century, "Lust and Liberty" does not-and cannot-delve into the questions of sequence, contingency, and irresolution that defined this moment. This is not just a question of depth versus breadth - it is, at its core, a question of analytic structure. An account that takes as its starting point a clear shift in attitude, one that traverses an entire century, is structurally unsuited to engage these processes of synchronic development, for to inhabit a moment fully, to probe these connections completely, would be to lose sight of the long trajectory. It would be ineffective storytelling. We cannot engage the momentary nature of a moment while treating the moment as a moment of transition because it is far from clear that all of any given moment's developments would lead in any one direction, let alone the direction being traced in any given account. Ultimately, then, we need the ambitiously diachronic to supplement the painstakingly synchronic, without dispensing with either, and without always trying to combine the two. The history of sexuality, like history in general, was a history that happened in multiple temporalities. The scholarship should capture this heterogeneity.

Almost as powerful as the long-term linear narrative is a concentric narrative which places sodomy, or homosexuality, at the center of all change. Sodomy, writes George Haggerty, is "central to the codification of sex and gender identity as well as to the formation of bourgeois domestic economy"-it is, he contends, "the node around which all the forces of culture are gathered." ${ }^{24}$ But Gabriel Laur-

${ }^{121}$ Dabhoiwala, "Lust and Liberty," 91-92.

122 Ibid., 92, 96.

${ }^{123}$ Ibid., 164.

${ }^{124}$ George Haggerty, "Keyhole Testimony: Witnessing Sodomy in the Eighteenth Century," Eighteenth Century: Theory and Interpretation 44, nos. 2-3 (Summer 2003): 180, 172. 
ence's untimely death does not support the image of sodomy as the centripetal magnet at the core of culture. Nor does the text to which Haggerty refers- the sodomy scene in Cleland's Fanny Hill —which, like the case of Laurence, suggests that culture might not have a single heart at all, that culture itself is dispersed and variegated, constantly shifting, always polycentric. It is not just sodomy we fail to understand-culture as a whole is obscured when thus envisioned as concentric. With sodomy at the center, the source of change and the source of all meaning, culture is deprived of its dynamism and contingency. We undermine our ability to gauge the extent to which sodomy itself is affected by culture-how society haunts the body's sexuality-when we place sexuality at the stable epicenter of society.

The path on which this essay is traveling was paved by the likes of Trumbach, Bray, and Haggerty, because of whose efforts the mollies first secured their place as a major chapter in the history of sexuality. As Tim Hitchcock writes, "the initial impetus for the expansion of this field was the increasing self-confidence and political activism of the modern gay community." ${ }^{125}$ To some extent, the particularities of this moment are reflected in the determined thrust of these arguments.

But for sodomy to be historically significant it need not be socially central, nor must it move in lockstep with the established axes of historical transformation. Indeed, it is precisely because the subject is so critically important that we need to remove it from an imagined stable center and, by so doing, engage the incoherence of the political field in which this history occurred. In her famous essay on gender, Joan Scott has argued that "we need to replace the notion that social power is unified, coherent and centralized with something like Foucault's concept of power as dispersed constellations of unequal relationships, discursively constituted in social "fields of force" "126 By so doing, we are better equipped to understand the origins of an event like the molly house executions. But we are also better emboldened to act in the world in which we live. An attention to incoherence can be politically useful, for it raises rather than diminishes possibilities for action. By failing to engage incoherence, we risk creating the impression that things could not have been different-that history moved in inexorable ways toward inevitable, predetermined conclusions - and, by extension, that things cannot be changed in the present. It was a wide range of cultural instabilities, many unrelated to sodomy per se, which made Edmund Gibson pursue Gabriel Laurence with such tenacity. By assuming that he did so solely for being influenced by a rising cultural homophobia we fail to understand the event and, beyond, the politics of sexual persecution writ large.

${ }^{125}$ Hitchcock, English Sexualities, 58.

${ }^{126}$ Joan Scott, "Gender: A Useful Category of Historical Analysis," American Historical Review 91, no. 5 (1986): 1053-75, 1067. 